\title{
HANDLING COLLECTIVE FEAR IN FOLKLORE
}

\section{Reet Hiiemäe}

Throughout centuries human fear has induced the emergence and formation of folkloric phenomena. It is characteristic of human nature to fight against fear, trying to reduce or prevent it, and this aim reverberates in the folk narratives. The mediation of fear in folklore does not, however, provide a tradition carrier relief from these fears, but proposes solutions (that can be materialised at least in narrative form) to handle them.

In the following I will analyse methods of coping with one of the main sources of human fear in narratives - namely, death and fatal diseases, which have been topical since the beginning of human thought.

Here I would like to point out three main aspects of fear in folklore

(i) The sc. mass fear (collective fear for epidemics and other catastrophes) reflected in folk narratives, whereas

(ii) universally threatening situations are often expressed by individual experience in narratives (like a contact with demonic supernatural beings), and we must also consider that

(iii) in the European culture the reflection of fear in folk mythology has been influenced by the propagation of guilt and punishment causality by the church (e.g. in legends about violating a moral code).

Legends present us a complex system for manoeuvring around the world filled with mythological dangers. Narrative samples with frightening ending should prevent a person from repeating the condemnable deed, helping thereby to escape a similar punishment, whereas legends that end happily for the main character illustrate the need to follow certain moral standards. The aim of the legends, obviously, is to mediate something more and not just imitate a real situation - the narratives are interpretations or elaborations of facts 
and can become accepted and understood in traditional narrative communication only as such.

It seems that the objective of plague narratives has not been to instruct readers how to eliminate dangers described in the text, but a rather, perhaps unconscious wish to reduce fear for the disease. Interestingly, fear as such is rarely mentioned directly in plague narratives, but it is always present.

\section{DEFINING FEAR}

Several narrative strategies are widely known in folk belief and mythology, but here I will observe them in the context of plague narratives. Plague epidemics (and plague narratives) have been the concern of vast masses of people and have influenced the mythological and religious worldview of the European countries (including Estonia) more than any other disease in the history of mankind. As we know, many regions of Europe suffered from the devastating waves of plague until the 18th century, and the plague was the most destructive in the 14th century when nearly one third of the European population perished in the epidemics or in war. Certainly, fear is not the only factor that has influenced the course of narrative tradition (I have addressed several issues concerning the relationship of and discourse on folk religion, mythology and medicine in my previous works, e.g. Hiiemäe 1999), but the current article focuses on the aspect of fear.

The analysis of plague narratives reveals that they focus mainly on the issue of survival, especially on (i) how to recognise a plague spirit and (ii) how to escape plague. The issue of survival may have been treated from a negative aspect - in such narratives the focus is on the destructive force of the plague spirit, but also on the statement, how the contagion could have been avoided. The corresponding binary oppositions occur also in the following text:

The plague disease came to the house threshold as a goat, sometimes as a bird, sometimes was known to look like a magpie. Whoever mentioned its name - fell down and that was it. Who did not utter a word - survived (Hiiemäe 1997: 158). 
Or another example:

Plague. My grandmother told that they saw how the plague killed people. As if an ashen spirit came, whoever touched it fell down like a log of wood. Whoever was awake stayed alive. But those who slept at that time had to be left behind (Hiiemäe 1997: 174)

Thus, even narratives about dying of plague often contain an idea that doing the right thing helps to escape the disease, reflecting both the harsh historical reality as well as the ideal solution of a danger situation. The importance of choosing the right conduct in folk tales is stressed in a structural-semantic work by B. Kerbelité, a Lithuanian folklorist, who claims that the outcome of an individual's conflict with creatures of the otherworld depends directly on the person's conduct (Kerbelité 1998: 16). Narratives were also the only place, where solutions that have no logic in reality would function perfectly. This viewpoint contradicts Lutz Röhrich's argument that folk tale style is principally pessimistic and an individual almost always looses the battle with supernatural forces (cf. Röhrich 1984: 174).

In order to be able to fight danger, it has to be recognised, i.e. it has to be defined. In folk tales the abstract sources of danger are often concretised, either

(i) by localisation, confining the danger to a particular location;

(ii) by personification; or

(iii) by vectorialisation, or by giving a direction or a course.

Association with a particular place seems to give an opportunity to control fear, or at least to prevent it to a certain extent. Or, in other words, Excessive fear for some danger is projected outwards and is associated with a particular location. An individual, then, did not have to keep the fear inside him, but the feeling of danger and fear was transferred to this place (Jeggle 1990: 62). Fear for ghosts, for example, was not felt everywhere, but in particular buildings, ruins or graveyards, which were renowned for being haunted. As to the more recent media-based narrative tradition, localisation is analogously applied to murder and crime scenes.

Generally speaking, the contact between humans and mythological beings in folk tales may take place on three planes: 
(i) a mythological beings enters the human domain (village, farm; this category includes most of the plague, nightmare and revenant narratives) (cf. the notion of the circle of home in Paulson 1997: $103 \mathrm{ff}$.);

(ii) the encounter takes place at a neutral ground (at a secluded place, on the road; the category includes several devil and ghost narratives);

(iii) a human enters the supernatural domain (graveyard, forest, water-body; includes legends about spirits, water sprites, forest nymphs).

These domains are by no means clearly distinguishable and may overlap, for example in cases when a location or an object of mythological importance (such as a tree, stone, etc.) is located in an otherwise neutral place. This indicates that supernatural creatures may be either stationary or mobile (the plague spirit belongs among the latter). Due to its gradual spread the epidemics could not be associated to a permanent place of origin, but it could be associated with a particular shape and direction. In several European mythologies the abstract, omnipresent plague contagion had assumed the shape of a man, woman or a boy, who must be killed in order to put an end to the epidemics in the tales. On the other hand, fear acquired mythological dimensions through personification; therefore, it does not disappear but re-emerges on another level, introducing new ideas and concepts. Erwin Möde, the German theologian and philosopher, has expressed a similar idea:

The relief accompanied by the externalisation of fear is certainly not a final achievement. [---] It is rather an intermezzo before the postponed return of the previously externalised fear. Having been repelled and smothered, the fear projected on the external objects, processes and temporal-spatial events returns in distorted form (Möde 2000: 10).

If a human from active mythological tradition enters such a mythologically-laden (both temporally and spatially) domain, his particular state of mind induces the intensification of fear and prepares him for the encounter with the creature. It is likely that this prompted people to regard certain persons or groups of persons as carriers of 
disease during the period of plague. Obviously, as long as the plague was popularly believed to be caused by plague-sowers or plague spirits, it was hardly possible to trace its actual sources and spread.

I would like to note here that in the period preceding modern medicine, plague and the following death tended to merge in one, since the time period between cause and consequence was unusually short (cf. Schläfer 1995: 281). Despite the huge numbers of fatalities, people did not know what plague really was. Death was personified, largely by the official church - promoted by pictorial representations of danse macabre in religious art as well as sermons on the topic -; the appearance attributed to death intended to advocate Christian piety and the perishability of life. The plague disease, on the other hand, was personified more spontaneously, in a way analogous to other mythological concepts. Although the anonymous disease, often called the Great Dying or the Black Death was attributed a certain personified shape in folklore, saying its name out loud was still a taboo. The 'name taboo' was known in folklore already before the massive plague epidemics, but with the plague it reached a new level. In Estonian legends about conversations with a plague goat it is especially conspicuous:

Once, during the old plague, a farmer's family sat down to eat dinner. The meal was a freshly baked bread that they dipped in saltwater.

There stepped in death in the shape of a goat and shouted:

"What a miracle! What a miracle! People eat fire and drink sips of sparks!”

The old mother on the oven replied:

"What a miracle! What a miracle! Who has ever heard that a goat speaks in human tongue!"

The goat angrily shook its head and left without harming anyone (Hiiemäe 1997: 330).

Folk narratives follow certain rules of logic, which cannot be applied to real life, and tradition carriers have probably not even assumed that they could. The folktale rules out the possibility that the plague goat may have misheard or misunderstood human lan- 
guage: uttering the right formula was always effective. Such response can be viewed as a double euphemism. Since mythological concepts are often contradictory - in some cases the recognition and calling the disease by name "scared" it away, while in other cases the person calling it by name fell victim to the disease -, then in this tale a compromise between both options has been reached: the disease spirit is not directly called by the name, but the response implies that it has been recognised. Recognising a demonic being was sometimes even more complicated that fighting against it. Malevolent supernatural beings often follow the same social norms like humans - e.g. they rarely break a promise, keep their word of honour, shy away at cock-crow, etc. Therefore, in order to precede harm and make a right move, first and foremost the spirit's nature must be determined.

\section{CATEGORISATION OF CHARACTERS IN FOLK TALES}

The spread and survival of folkloric phenomena depends, among other things, on their susceptibility to the different interpretations by informants/mediators/audience. Plague narratives include numerous examples of combinations in determining the nature of the narrative character or in viewpoints to their position in an imaginative system of belief value. According to folk tales, a plague spirit usually appeared in an ordinary human shape, attired in ordinary clothes, nothing in its appearance suggesting its deadly nature, except, perhaps, the fact of being a stranger. At the same time plague narratives introduce other strangers, who have been described as odd lodgers, beggars, travellers, etc. - such appearance may have pointed to any of the four types of status:

(i) plague spirit

(ii) harbinger of plague

(iii) plague-sower (in few cases a plague-sower may have been an acquaintance)

(iv) plague preventer.

All four are associated with the arrival of the plague epidemics in folk tales, but their different standing is revealed in the following course of events (a boy with a stick starts poking other people; a strange traveller gives good advice, etc.). The plot is interpreted 
and the standing of the character is determined by the narrator or an eye-witness to the event. Village people may have, in fact, become infected by odd travellers of refugees, thus when the arrival of a stranger in a village - which was very rare at the time - caused the emergence of the disease, he was categorised among negative characters. A narrative plot may have contained ambivalence - an originally harmless traveller monk or an old man proved to be a plague spirit, or, vice versa, a person associated with plague turned out to be an ordinary villager - but the narrator's evaluation reflected in the text is the same and final from the beginning to the end.

In some folk tales the stranger meets certain criteria, followed by the categorisation according to those criteria, but often no such features are mentioned. In the following text, for example, one of the boys is categorised as plague and another one as a benevolent helper with no further explanation:

The landlord of Rummu once announced that the plague was coming to the Neeme village. He had told people to wash themselves and prepare for death.

A vagrant boy came to a family and asked for lodging. The family told the boy that they will die and that they can take nobody in. The boy kept begging that if they took him in, they would escape death. At last, the family agreed.

The plague was believed to come in the shape of a young boy. The boy was sent by the landlord. He was holding a stick which was dipped in poison. When the plague boy came to the family's house through the window, the vagrant boy jumped up and killed the plague boy. And nobody died (Hiiemäe 1997: 284).

Apparently, the narrator has not considered it necessary to explain why the vagrant boy was not considered to be the plague, though it was known that the disease will come as a strange boy. The status of the character was therefore not final, and since the stranger was attributed the role of the preventer rather than the role of a plague spirit, he became a positive character. We may assume that in potential danger people may have attributed more than one role to a stranger, and this did not exclude even completely contradictory roles. In only one tale the narrator has not been certain in the categorisation of a stranger: 
Of the plague he told that one pale beggar-like old man came by. Was that the plague or did he just spread it? Don't know (Hiiemäe 1997: 119).

The following example obviously describes a harbinger of plague, who would rather prevent the catastrophe from happening. According to a German legend an old man with fearsome appearance lied on the field and nobody wanted to take him along. Finally a farmer picked him up and the old man told him that he was a harbinger of plague and advised him to run away to the woods until he sees a white goose swimming downstream. This was supposed to be a sign that the disease has passed (see Veckenstedt 1880: 330). In an Estonian tale a stranger also advises to go and hide in the woods until the epidemic is over, but here it is specified that the stranger was a plague boy (Hiiemäe 1997: 277). In the following Estonian tale, however, the man who appears may be seen as a harbinger of plague:

A long time ago, on a New Year's Eve, Rein, the overseer of the Haeska estate, walked home from Rannamõisa. Arriving at a path's end in the pine grove he was startled by a man, stained with blood, standing next to the path and saying: "Go and tell all the people in your village, that who wishes to escape from plague should hurry and flee from the village with their animals and things and should follow the road where the seven roads cross. They should take the seventh road, and there is no danger of plague anymore." [---] A week following the incident severe plague broke out in the village and killed many people. The two farmers who had followed the advice, were untouched by the plague (Hiiemäe 1997: 288).

Assuming that the legend is based on reality, the harbinger may have been someone coming from the infected neighbouring village, whom the narrator attributed supernatural features in the course of narration, either due to his prophetic message or for some other reason. Also, the following listeners/narrators have an opportunity to revise the categorisation of previous narrators. In some tales the narrator's evaluation differs completely from the categorisations presented in the plot - the narrator transmits the traditional text unit but also expresses his contrary view, as in the following example: 
Right here, across the road, there was an old threshing barn. A plague went over it on a Christmas Eve. Everyone was sleeping in the straw and a tiny man came in through the door and poked around with his stick. Whomever he touched that died. An old maid had woken up and spoke in great fear-she was the only one who stayed alive.

I personally believe that how could then the plague be better than it is now, but at that time there were these smoke rooms and people suffocated in the fumes. Some half-dead saw some smoke and that was this pale man (Hiiemäe 1997: 191).

In the tales where an unfamiliar man or boy has been categorised as plague-sower, the supernatural recedes to the background and the danger becomes imminent, because the person who unleashes it is a member of the same community. Attributing an ailment caused by an unknown source to an actual existing object does reduce fear, as the attention is focused on the substituted object, which can be removed, but not on fear itself, which is something that cannot be removed. But it also causes a certain demonisation of fellow people. The disease is no longer brought about by the wrath of a righteous god, which is generally accepted, since people believe they deserve it, but by an unforeseen evil of another person, which is regarded as unjustified and the source of which deserves the punishment.

Röhrich, for example, has also mentioned that during confrontation with an unfamiliar opponent, a stranger is often demonised (Rörich 1984: 180). Searching for and finding a scapegoat is not a solution to the problem, but only redirects attention.

If we observe the described folk tale from the morphological viewpoint, we will realise that the functions discovered by Vladimir Propp in Russian fairy tales are not applicable to plague narratives, as it is often impossible to determine whether a particular tale character is an antagonist or a positive figure. The estimation on the nature of character depends on a particular narrator, not some inflexible text-internal structure. The comparison indicates that in fairy tales the roles of characters are more fixed and less narrator-dependent than in legends. As the whole fairy tale is set in other realms than in the real tangible world, a narrator, as the repre- 
sentative of this world, has little to say on the categorisation of fairytale characters.

We may prove with relative confidence that virtually all plague narratives follow Propp's functions 'deficiency > elimination of deficiency', whereas in plague narratives the underlying functions are 'outbreak of the plague $>$ end of the plague' and in narratives describing life after the epidemic 'searching for partner $>$ finding a partner'. I agree, that the outcome is too trivial to be called morphological evidence. If this was the case, we could also argue that Christianity has conditioned the formation of such structure logic in the European folk tales - in numerous Western plague narratives the only thing that would eliminate 'deficiency', i.e. end plague, is praying or erecting a church (whereas the disease that created the need for eliminating deficiency in the first place, has the same origin than the means for its remedy). Still, there is no doubt that illness as a punishment, or a form of social control, had roots in traditional thought already before the arrival of Christianity. The concept of illness breaking out as a punishment for violating social norms and taboos, mostly directed at one particular person involved in it, was known in Christian and non-Christian societies alike. It appears that Christianity has therefore only shaped the idea that was previously already there, and has been a good ground for the idea of epidemic diseases as a form of collective punishment.

\section{PLAGUE AS A COLLECTIVE DISEASE}

The concept of an abstract godly revenge directed at the whole humankind as well as the dominant idea in plague narratives, where infection is always preceded by an encounter with a plague spirit or by a contact with the poison spread by plague-sowers, refer to the fact that from early on people must have been aware of the social nature of plague. In folk tales, religion and medicine, plague was a phenomenon which prerequisite was the presence of a group of people. Let me illustrate it with the wheel metaphor. As long as a wheel is intact (an incessant closed circle), it functions perfectly. Analogously, the prerequisite of the continuous spread of plague is human contact, the existence of social units. The wheel stops at the dysfunction of a single link - similarly, the plague, when missing a 
single link in the chain of contagious people, has to stop. A comparison of concepts connected to plague spirits in different traditions reveals that the motif of a plague-carriage breakdown is known only in the Estonian tradition, though the motif of plague using a vehicle is quite common in West-European legends. The Estonian example reads as follows:

Once the plague raged among people again, coming from Narva, where it had set out and moving towards Tallinn.

Having reached the Kivikatku [lit. the Stone Plague] farm in the Palmse parish, the plague's rage stopped. Since the wheel of the plague broke at this point, the farm is now known [by the name] Kivikatku (Hiiemäe 1997: 369).

In this story type the plague spirit, as a mythological beingq, is driving a vehicle with all the characteristics of a real world carriage. The image of a carriage helps to determine the direction of the epidemics, whereas the carriage itself is breakable indicating that the epidemic as a whole is stoppable. As such the irrational danger becomes a directed entity, which may fall upon humankind on three levels:

(i) individual level,

(ii) microlevel (family), and

(iii) macrolevel (a larger community - a village or a town),

whereas on the second and third level the attack automatically comprises the previous levels, as each level is a part of the next one. Similarly, fighting against plague may also take place on three levels. Unlike other tales about experiences with supernatural creatures, where the individual encounter is an important component of the tale (e.g. accounts about encounters with misleaders, fairies, nightmares or ghosts) (cf. Petzoldt 1999: 59), in plague narratives the emphasis is on the collective nature of experiencing illness. The role of the whole community in conquering the disease is stressed particularly in the plague prevention of Western European countries, consisting of common prayers, bordering villages, erecting a church or a chapel. Here an important role is played by religious reasoning, according to which a collective punishment can be redeemed only through collective penance. This applies to legends about survival, of course. However, according to a grimmer inter- 
pretation about AIDS in modern urban legends it is a collective inevitability. The scary feeling that no-one is safe is manifest in legends about imperceptible criminals who consciously try to infect as many innocent victims as possible and drag them along to share a common tragic fate. This motif is similarly common to the tales about plague, AIDS and anthrax.

\section{UNIVERSALITY OF TRADITION}

Another issue that emerges in the study of narratives about epidemics, as well in folklore in general, is the issue of universality. Overcoming different types of fear (e.g. the discovery that an illness was caused by bacteria rather than a disease spirit or the wrath of gods) brings along changes in people's mentality. Although their worldview will still largely depend on their fears, the focus is shifted and new combinations are formed in the tradition. Each religion provides solutions but also introduces new questions and fears that the society needs to sort out on their own. Fear and the intensity of fear are caused by the religious and social situation of a particular era (Röhrich 1984: 173). In medieval times people feared the wrath of god and felt powerless against the resulting plague epidemics. In modern secularised world the plague sent by God is no longer feared - people fear diseases produced in laboratories by men, which may at one point turn against people like them. The fear that a disease may take control of a man still persists.

We can also speak about the cyclic re-emergence of fears - latent fears activate over certain periods of time and the universal strategies of coping with them will appear in oral narrative tradition. No instances of plague have been registered in Europe over the past three hundred years, and the fears associated with it seemed to have been long forgotten - only to re-emerge in connection with the few dozen anthrax cases in the United States in the late autumn of 2001. Apparently, people from the First World countries are unaware of the fact that the same disease demands thousands of fatalities each year in poor Asian and South-American countries - or, in this connection they take it as a legitimate, "normal" death, which causes neither panic nor provokes discussions, because this is how it has always been. How- 
ever, when a disease breaks out in a zone that has been previously considered safe and the outbreak is emphasised by a striking news story - associating elusive terrorist attackers lurking everywhere and massively spreading deadly bacteria by correspondence - , then it suddenly becomes unexpected and horrifying and seems to affect everyone.

Unlike the plague bacterium Pasteurella pestis, which caused widespread epidemics in Europe in the $14^{\text {th }}-18^{\text {th }}$ century, anthrax or the Siberian plague, though also caused by bacterium (Bacillus antracis), is not infectious through human contact. The only form of anthrax that is fatal to humans is the inhalational anthrax, which infection by correspondence is virtually impossible. This, however, is not a kind of information you hear when people talk about anthrax. Conversation topics tend to be limited to the main cause of fear, because being well informed (even if unofficially) about the disease may mitigate worries.

Quite surprisingly, in everyday conversations anthrax is also associated with the historical plague epidemics (perhaps similar symptoms, like black spots and boils on skin, have something to do with it). While in the Middle Ages it was considered a taboo to speak about the plague, people now try to overcome fear by directly addressing it - for example, through black humour on AIDS and anthrax ("December 1st is the World AIDS Day, you don't have to worry about getting infected that day!"). Also it is common to "diagnose" someone complaining about poor health: "It's probably anthrax!" Urban legends about letters containing white powder, which eventually turns out to be something quite ridiculous (such as flour, laundry detergent or make-up powder), also help to reduce fear. But there are other possibilities - for example, a few weeks following the first anthrax cases in the news, an accountant said that all her clients who happened to bring her an envelope containing documents made a joke that they had also added some powder. Such a seemingly arrogant approach to the issue seems to be characteristic particularly of smaller nations, like the Estonians, who feel quite safe about the matter. Attempts to reduce fear through ridicule are, in fact, quite common. We still have reason to believe that the historical plague disease has not been a subject of ridicule - particularly because it was a global 
problem, directly affecting the narrators who spoke about it - , but it was widely spoken about in other forms.

With modern means of communication, which protects narrator's anonymity but enables a wider spread, electronic mail is increasingly becoming an effective means for reducing fears. In the United States, in particular, misleading e-mails warning against using public pay phones, automatic gas stations, etc., the slots of which may contain AIDS-infected needles put there by minions of the invisible AIDS mafia, are very common. Usually, the warning letter appears to have been sent by some leading institution, such as a rescue service or an epidemiology lab, but further checking reveals that the named institution has no knowledge of nor confirms information contained in the letter (cf. hoax981128). I believe that it does not take very long before similar warnings about anthrax will be in circulation. Here, again, the sending of the letter intends to reduce the sender's fear.

In early winter 2003 media channels swarmed with news about SARS, the new and dangerous disease. Speculations about its causes soon began to spread. People believed they were informed relying on medical research, as a reliable source, that they had reportedly heard over the media: Now, by the way, it has been determined that SARS is not a virus at all, and wearing these facial masks is just nonsense. The disease has appeared because human organisms have been so impaired by the genetically mutated foods that their immune systems have simply stopped functioning normally. And this will only get worse (female, $46 \mathrm{yrs}$, Tartu, in May 2003). A fear for an unknown disease is associated with fears and disbelief towards modern technology. Sometimes, however, the source of the disease is tried to be localised to a strange culture, which seems frightening and dangerous already because of the strange and unfamiliar customs. A 33-year-old man, for example, claims that he heard over "Raadio 2 (a commercial national radio in Estonia) or some other station" that humans became infected from the contact with cats, who in this Asian country where SARS reportedly broke out, are considered a gourmet delicacy (male, 33 yrs, Tartu, May 2003). Defining the source of danger, although fictional, enables to outline and localise the danger - these are the same processes than those described in connection with plague narratives. 


\section{CONCLUSION}

The general rationalising of human worldview has deemed several popular strategies unimportant. But since many fears (though modified) are still topical, regardless the rationalisation, it is possible to observe some universal features that have been retained in popular thought over the centuries. Knowledge of these processes enables us to understand the established human behavioural patterns, predict future behaviour and eliminate social stress.

Translated by Kait Tamm

\section{References}

Hiiemäe, Reet 1997. Eesti katkupärimus. Monumenta Estoniae Antiquae II. Eesti muistendid. Mütoloogilised haigused I. Tartu: EKI folkloristika osakond, EKM Eesti Rahvaluule Arhiiv.

Hiiemäe, Reet 1999. Eesti katkupärimus Lääne-Euroopa katkutraditsiooni piirimail. MA manuscript. Tartu University.

Jeggle, Utz 1990. Tödliche Gefahren. Ängste und ihre Bewältigung in der Sage. Zeitschrift für Volkskunde, 86, pp. 53-66.

Kerbelite, Bronislava 1998. Contemporary Legends: The Continuity of Tradition. Perspectives on Contemporary Legend. 16th International Conference July 21-24, 1998. Program. Innsbruck: ISCLR \& University of Innsbruck.

Möde, Erwin 2000. Apokalyptische Endzeitängste zur Jahrtausendwende. Leben zwischen Angst und Hoffnung. Interdisziplinäre Angstforschung. (Eichstätter Studien, XLIV.) Regensburg: Verlag Friedrich Pustet, pp. 9-22.

Paulson, Ivar 1997. Vana eesti rahvausk. Usundiloolisi esseid. Tartu: Ilmamaa

Petzoldt, Leander 1999. Einführung in die Sagenforschung. Konstanz: Universitätsverlag Konstanz.

Röhrich, Lutz 1984. Sage-Märchen-Volksglauben. Kollektive Ängste und ihre Bewältigung. Angst und Hoffnung. Grundperspektiven der Weltauslegung (Mainzer Universitätsgespräche Wintersemester 1983 / 84 und Sommersemester 1984.) Günter Eifler, Otto Saame, Peter Schneider (eds.), pp. 173-202.

Schläfer, Daniel 1995. Texte vom Tod. Zur Darstellung und Sinngebung des Todes im Spätmittelalter. (Göppinger Arbeiten zur Germanistik 620.) Göppingen: Kümmerle Verlag.

Veckenstedt, Edmund 1880. Wendische Sagen, Märchen und abergläubische Gebräuche. Graz: Verlag von Leuschner \& Lubensky. 


\section{Internet sources}

Korova Multimedia (http://www.korova.com/virus/hoax981128.htm Mai 12, 2004). 